\title{
WOOD COFFINS IN SELAYAR AND THEIR COUNTERPARTS IN SEVERAL REGIONS IN THE PROVINCES OF SOUTH SULAWESI AND SOUTHEAST SULAWESI
}

\section{Wadah Kubur Kayu di Selayar dan Perbandingan dengan Beberapa Daerah di Provinsi Sulawesi Selatan dan Tenggara}

\author{
Bernadeta Apriastuti Wardaninggar \\ Balai Arkeologi Provinsi Sulawesi Selatan \\ Jl. Pajjaiyang No. 13 Sudiang Raya Makassar, Indonesia \\ bernadeta.akw@kemdikbud.go.id
}

Received: 04/12/2020; revision: 26/01-07/06/2021; accepted: 07/06/2021

Published online: 30/06/2021

\begin{abstract}
Abstrak
Penelitian ini bertujuan untuk mengetahui distribusi wadah kubur kayu yang diletakkan di gua-gua di Kepulauan Selayar dan perbandingannya dengan beberapa daerah di Sulawesi Selatan dan Tenggara. Dalam pencapaiannya, selain diuraikan bentuk-bentuk wadah kubur kayu di gua-gua Selayar, juga dilakukan deskripsi temuan sejenis di Bulukumba, Enrekang, Toraja (Sulawesi Selatan) dan Kolaka Utara (Sulawesi Tenggara). Metode yang digunakan adalah studi literatur (desk study), yaitu mencari dan menghimpun berbagai referensi berkaitan dengan topik penelitian. Selanjutnya dilakukan pengolahan data dengan disertai analisis bentuk, sebaran dan etnografi serta pembuatan peta. Hasil penelitian menunjukkan bahwa distribusi wadah kubur kayu baik di pesisir maupun di pedalaman Sulawesi Selatan terdapat di Selayar, Bulukumba, Enrekang dan Toraja. Demikian pula di Sulawesi Tenggara wadah kubur kayu ditemukan di gua-gua khususnya di daerah Kolaka Utara. Dari data literatur menunjukkan wadah kubur kayu berawal di Toraja sekitar abad ke-8 $M$ dan mengalami perkembangan pada abad ke-12 dan ke-13 Masehi. Kontinuitas tradisi itu masih berlangsung di Toraja yang merupakan daerah pegunungan yang secara geografis cukup terisolir sehingga lambat dalam memperoleh perubahan budaya pada masa-masa tertentu. Secara etnografis, wadah kubur kayu yang digunakan oleh sebagian masyarakat Toraja sekarang memiliki perbedaan secara tipologis. Berbeda dengan Enrekang, meskipun terletak pada topografi perbukitan dan pegunungan, namun masyarakatnya tidak lagi menggunakan wadah kubur kayu disebabkan kuatnya pengaruh agama Islam. Kata Kunci: Wadah kubur kayu, tradisi, distribusi, pesisir, pedalaman.
\end{abstract}

\begin{abstract}
This research aims to establish the distribution of wood coffins placed in caves in Selayar Islands and their counterparts in several regions in South Sulawesi and Southeast Sulawesi. To meet the aim, the research describes the forms of wood coffins placed in caves in Selayar, Bulukumba, Enrekang, and Toraja (South Sulawesi) and Kolaka Utara (Southeast Sulawesi). The method used was literature study (desk study), which comprises the activities of finding and collecting various references related to the research topic. The collected data were analyzed to find out the forms, distribution and ethnography of wood coffins in those regions. A map of the distribution of wood coffins in the regions was also made. The results of the research show that the distribution of wood coffins in the coastal areas and hinterlands in South Sulawesi is found in Selayar, Bulukumba, Enrekang and Toraja. In Southeast Sulawesi especially in the region of Kolaka Utara, wood coffins are found in caves. The data collected through literature study show that the tradition of using wood coffins started in Toraja around the 8th century and experienced rapid development in the 12th and 13th centuries. Today the tradition is still performed in Toraja. This region is mountainous, so that it did not undergo rapid cultural changes in some certain eras. Ethnographically, the wood coffins now used by some of the Toraja communities have typological
\end{abstract}


differences compared with the ones used in the past. Enrekang is also a mountainous area. However, the community does not use wood coffins anymore due to the strong influence of Islam.

Keywords: Wood coffins, tradition, distribution, coastal areas, hinterlands.

\section{INTRODUCTION}

The coffins commonly used in South Sulawesi and Southeast Sulawesi in the preIslamic period are wood coffins placed in natural caves (Duli, 2013; Hasanuddin, Umar, \& Asfriyanto, 2005, pp. 130-131; Wardaninggar, 1998, 2011). Wood coffins have been used by the communities living in coastal areas and hinterlands. This is indicated by the distribution of wood coffins in various forms in those two areas in several regions of South Sulawesi and Southeast Sulawesi. In this research, the forms of wood coffins are studied and only wood coffins used in South Sulawesi and Southeast Sulawesi are studied. Wood coffins in Mamasa are not studied because the region is part of West Sulawesi and its culture and the culture of Toraja are considered as a one whole (Duli, 2012).

As is known, the distribution of wood coffins in South Sulawesi is quite wide, covering Selayar, Bulukumba, Enrekang and Toraja (Busthanul, 1991; Faiz, 2008; Hasanuddin, 2009; Somba, 1999). In Southeast Sulawesi, wood coffins are found in Kolaka Utara Regency (Wardaninggar, 1999).

In South Sulawesi, wood coffins are called erong, mandu or duni and allung. The term erong is commonly used in the region of Toraja. The terms mandu and duni are used in the regions of Enrekang and Luwu (Sriputri, 2013; Wardaninggar, 2011, p. 133) while allung is used in the region of Bulukumba. In Southeast Sulawesi and Central Sulawesi, wood coffins are known as soronga (Arsyad, 2017).

There is a variety of wood coffin forms distributed in several regions. Wood coffins in Toraja, for example, are in the forms of a pig, a buffalo and a customary house of Toraja (tongkonan). Wood coffins in Selayar, Bulukumba and Enrekang are in the form of a boat while in Southeast Sulawesi, they are in the forms of a mortar and a boat.

Historically and archaeologically, Selayar Islands is well known because it has a number of archaeological sites, from prehistoric Austronesian sites through Islamic sites to colonial sites (Bulbeck \& Hakim, 2005; Hasanuddin, 2009, pp. 83-98; Kadir, 1989, pp. 90-106; Pelras, 2006, p. 27; Somba, 1999; Wibisono, 1991). Wood coffins have been investigated by the Archeology Office of South Sulawesi (Laporan Penelitian Arkeologi di Kabupaten Kolaka Utara, 2008; Wardaninggar, 1999). The results of their research show that wood coffins are used for secondary burial.

A deeper research has been conducted by Duli (2012). The research elaborates the diversity of wood coffins in Toraja, Enrekang and Mamasa. He found out that the tradition of funeral with a wood coffin started in Tana Toraja around $1130 \pm 50$ BP (Duli et al., 2019, p. 5), in Enrekang around $790 \pm 50 \mathrm{BP}$ to $570 \pm 40 \mathrm{BP}$ and in Mamasa 730 $\pm 50 \mathrm{BP}$ (Duli, 2013). The results of the research prove that the tradition of funeral with a wood coffin was performed around the 8th century and in Toraja and Mamasa the tradition is still performed today.

Researches on wood coffins in Batu Baba Cave di Selayar have been conducted by Hasanuddin (2009) and Harsyad (1993). The researches found five caves that contain wood coffin remnants. The coffins contain some human bone remnants and grave goods, such as items made of bronze, earthenware and foreign ceramics. Some of these goods are decorated with geometric 
(triangle) and floral (leave) patterns carved on the coffin's body (Harsyad, 1993, p. 84). Data obtained from the literature study were analyzed to establish the artifact types and spatial distribution of the wood coffins found in caves as the cultural heritage from the Austronesian people (Simanjuntak, 2008; Simanjuntak \& Widianto, 2012).

The research problem is related to the forms of the wood coffins found in caves in the coastal areas and hinterlands of South Sulawesi and Southeast Sulawesi. The forms of wood coffins are certainly related to the ideology of the community who uses them. Considering all this, the following research questions are formulated: (1) what the forms of the wood coffins found in South Sulawesi and Southeast Sulawesi are and how their distribution is; (2) what factors have caused similarities and differences in the forms of wood coffins found in South Sulawesi and Southeast Sulawesi.

\section{METHOD}

In this research, the elaboration of wood coffin remnants in Selayar Islands was based on the data obtained from the literature study. The forms of wood coffins in Selayar Islands were then compared with the forms of wood coffins in some other regions in South Sulawesi and Southeast Sulawesi.

The research started with an exploration of secondary data, i.e. literature data relevant to the research's theme (Moleong, 2008, p. 82; Saifuddin, 2001, p. 91). The literature data explored were written data related to the researched sites. The data were from various resources, whether they are archaeology publications or ethnography writings related to the research subject. Furthermore, the literature data explored were also in the forms of figures, photographs and maps. With regards to this, maps were made based on the astronomical positions of the researched sites shown in some previous research reports.

The research approach was the comparative one. Applying this approach, the obtained data were compared. The comparison was conducted to find out differences and similarities among the data. Wood coffins from the following regions were compared: South Sulawesi Province (Bulukumba Regency, Enrekang Regency and Tana Toraja Regency) and Southeast Sulawesi Province (Kolaka Utara Regency). The comparison was aimed at finding out the similarities and differences in forms among the wood coffins and identying the types of the wood coffins from each of the regions. The above comparison entails a comparison of wood coffins in the coastal areas, such as Selayar, Bulukumba (South Sulawesi) and Kolaka Utara (Southeast Sulawesi), and wood coffins in the hinterlands, such as Enrekang and Toraja (South Sulawesi).

The forms, distribution and ethnographic aspects of the wood coffins were analyzed. An ethnographic study was conducted in the region of Tana Toraja. The analysis of forms was conducted by observing the forms of wood coffins found in all the researched regions. The ethnographic analysis was conducted to find out how the wood coffins were traditionally used by the community, the factors that have caused the tradition to be still used by some communities, and the factors that have made some communities leave the tradition.

The spatial analysis was conducted to find out the spatial distribution of the wood coffins in the coastal areas and hinterlands and establish their similarities and differences. The analysis helped establish that the same cultural roots became a factor causing similarities among the wood coffins and that innovation and creativity of the communities became a factor causing differences among them.

\section{RESULTS AND DISCUSSION \\ 1. Wood Coffins in South Sulawesi}




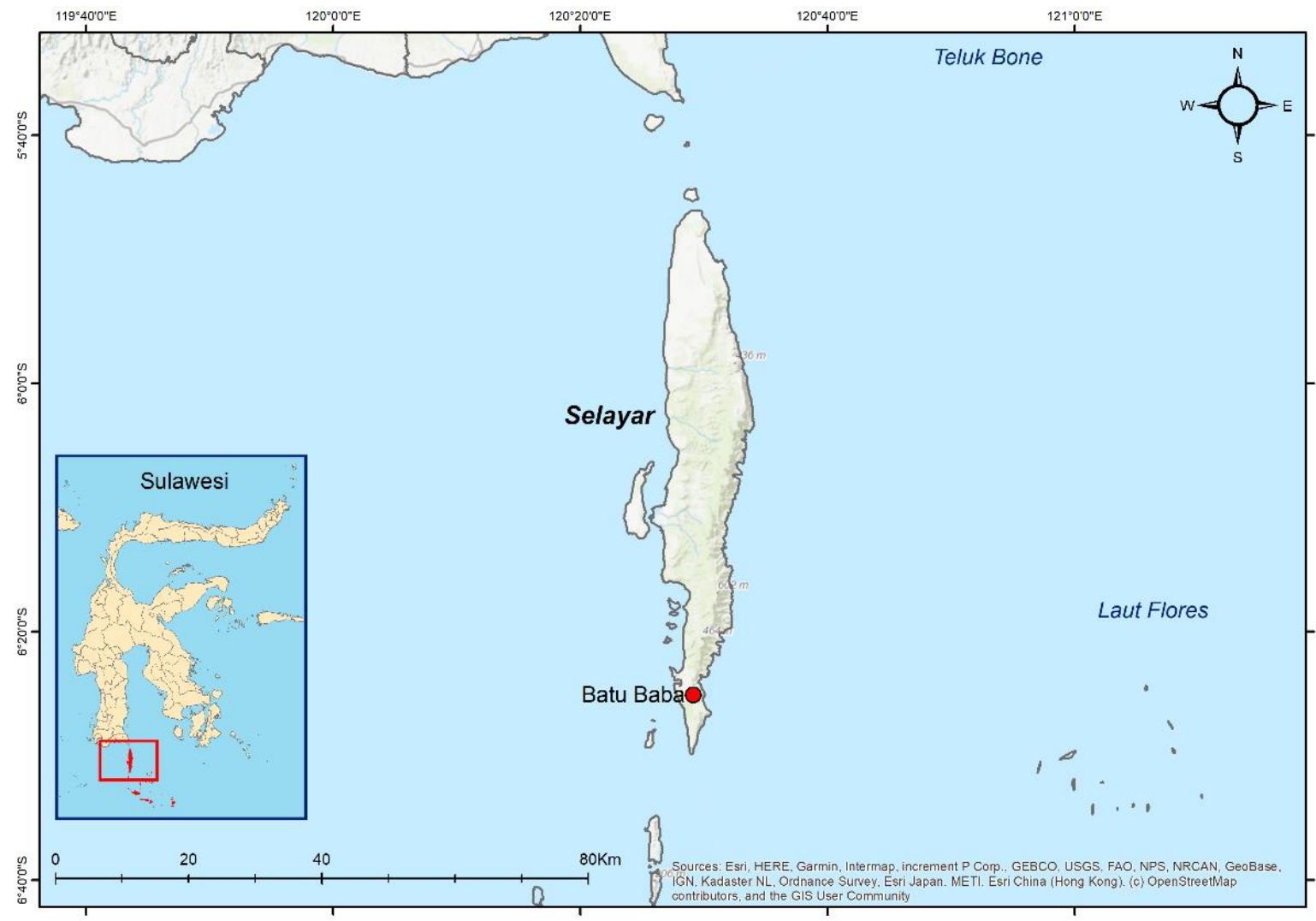

Figure 1. The location of Batu Baba Cave in Kepulauan Selayar Regency (source: the coordinates of the location as shown in Faiz's research, 2008)

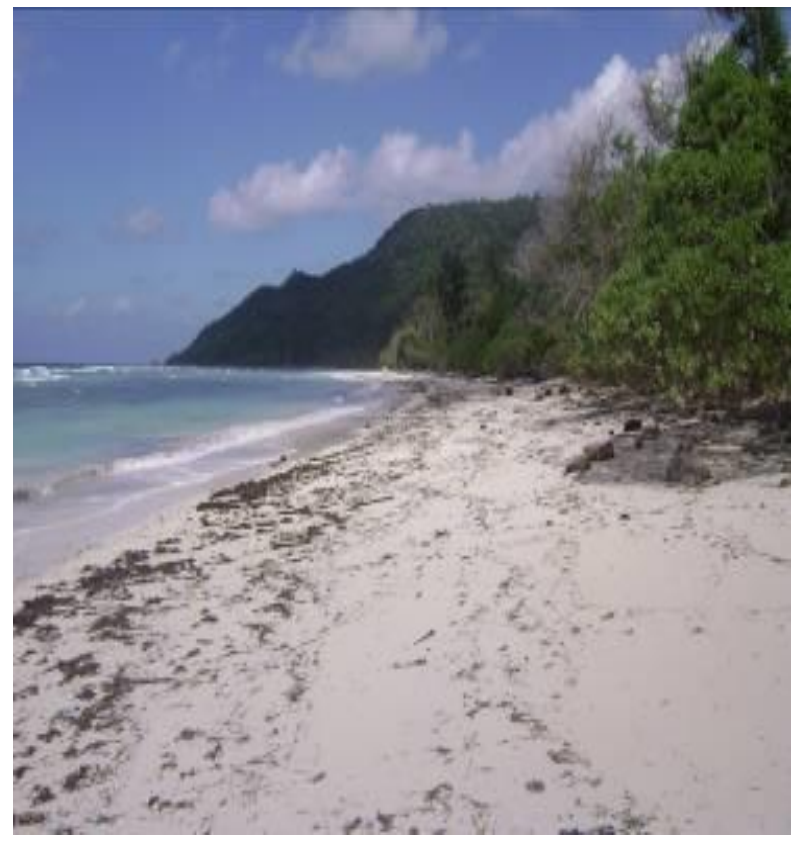

Figure 2. Condition Batu Baba Cave in Selayar (source: Faiz, $2008: 38$ )

\section{a. Selayar}

In the eastern coastal area of Selayar, there is a cave that contains archaeological

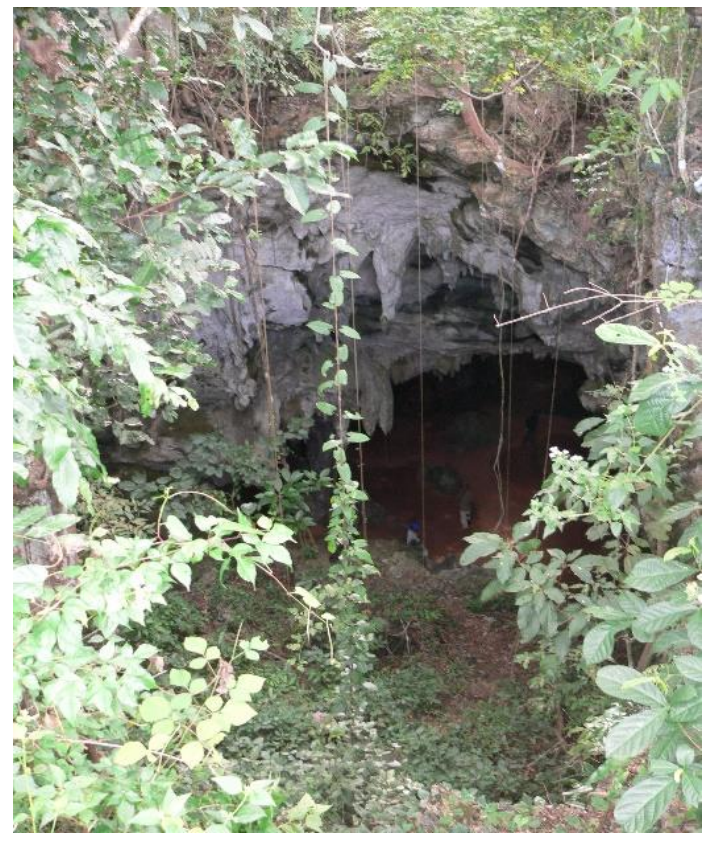

Figure 3. The nature around Batu Baba Cave in Selayar (source: Faiz, 2008 : 38 and 39)

evidence in the forms of wood coffins containing human bone remnants and earthenware fragments. The local 


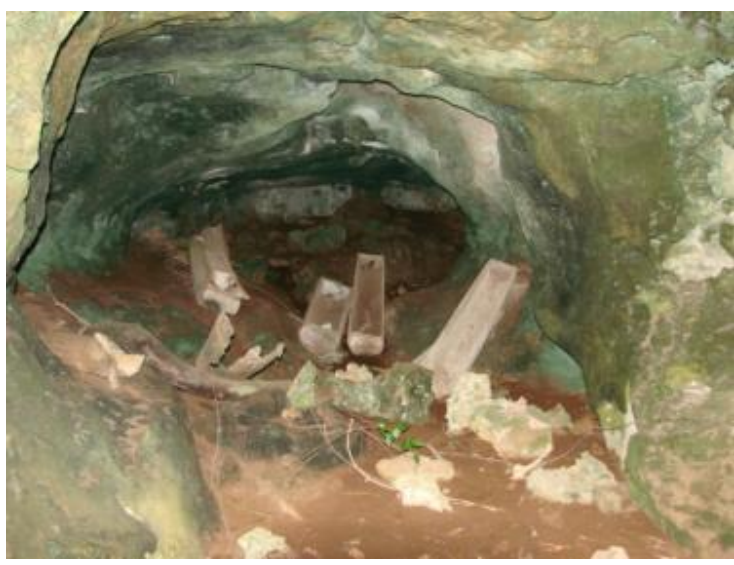

Figure 4. The entrance of Batu Baba Cave in Kepulauan Selayar Regency, where some wood coffins are placed (source: Hasanuddin, 2009,p.

90)

community calls the cave Gua Batu Baba (Batu baba Cave). The cave is situated in Barang-Barang Hamlet, Lowa Village, Bontosikuyu Sub-district (Harsyad, 1993; Hasanuddin, 2009), at the coordinates of $06^{\circ}$ $25^{\prime}$ 66.0" South Latitude - $120^{\circ} 29^{\prime}$ 96.7" East Longitude (Faiz, 2008, p. 37). Since Batu Baba Cave is situated in a coastal area, the wood coffins found in the cave may provide useful information on the forms of wood coffins used in coastal areas (Figures 1,2 and 3 ).

The wood coffins that are still intact are in the forms of a boat (Bernadeta, 1999: 81 ) and equipped with a cover. Some other coffins have lost their cover. These boatshaped coffins are decorated with tumpal motives on the lower part and the cover (Hasanuddin, 2009: 89-90). The back of the cover is decorated with geometric motives. The form of the cover is like the roof of the ethnic house of South Sulawesi. Besides wood coffins, some artifacts have also been found in the cave, namely beads, earthenware fragments, foreign ceramic fragments and bronze artifact fragments (Harsyad, 1993, p. 34; Somba, 1999, p. 74).

One of the rooms in Batu Baba Cave, which has the dimensions of $30 \mathrm{~m}$ (length) $\mathrm{x}$ $9 \mathrm{~m}$ (width) $\times 8 \mathrm{~m}$ (height), has 15 wood coffins that are still intact. Besides these

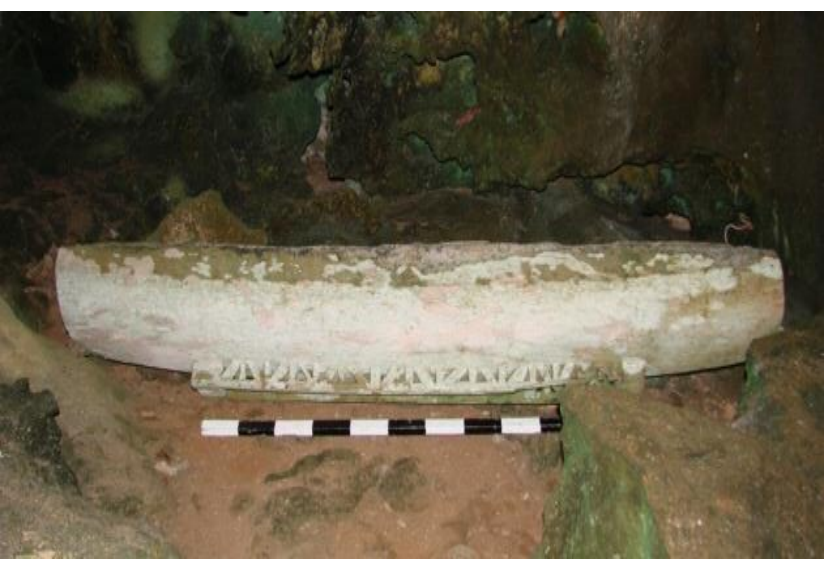

Figure 5. One of the wood coffins in the form of a boat found in Batu Baba Cave in Kepulauan Selayar Regency

(source: Hasanuddin, 2009, p. 89)

intact coffins, there is a countless number of damaged coffins. The length of the coffins is varied, between 1.92 and $1.96 \mathrm{~m}$. The width is between 30 and $40 \mathrm{~cm}$. The depth is between 17 and $19 \mathrm{~cm}$. The length of the coffin covers is between 1.35 and $2.30 \mathrm{~m}$ and the width is $40 \mathrm{~cm}$ (Figure 4) (Hasanuddin, 2009, p. 91).

Wood coffins in Batu Baba Cave are in the form of a semicircle, which is like a boat, and made of a log of tree (Figure 5). A previous research found that the material of the coffin is a $\log$ of bitti tree (Vitex Cofasus), which is easily found around the site. Bitti wood is a type of wood that is resistant to temperature changes and insects (termites), so that it does not rot easily and has a long-term durability. The dimensions of the coffins are varied. The length is between $125 \mathrm{~cm}$ and $230 \mathrm{~cm}$. The width is between $50 \mathrm{~cm}$ and $35 \mathrm{~cm}$. The height is between $20 \mathrm{~cm}$ and $22 \mathrm{~cm}$. The depth is between $20 \mathrm{~cm}$ and $23 \mathrm{~cm}$ (Duli, 2012, p. 216; Harsyad, 1993, pp. 40-42).

\section{b. Bulukumba}

Bulukumba Regency lies in the southern part of South Sulawesi. Its topography is dominated by lowlands and bumpy hills. Geographically, Bulukumba consists of two coastal areas, namely the 


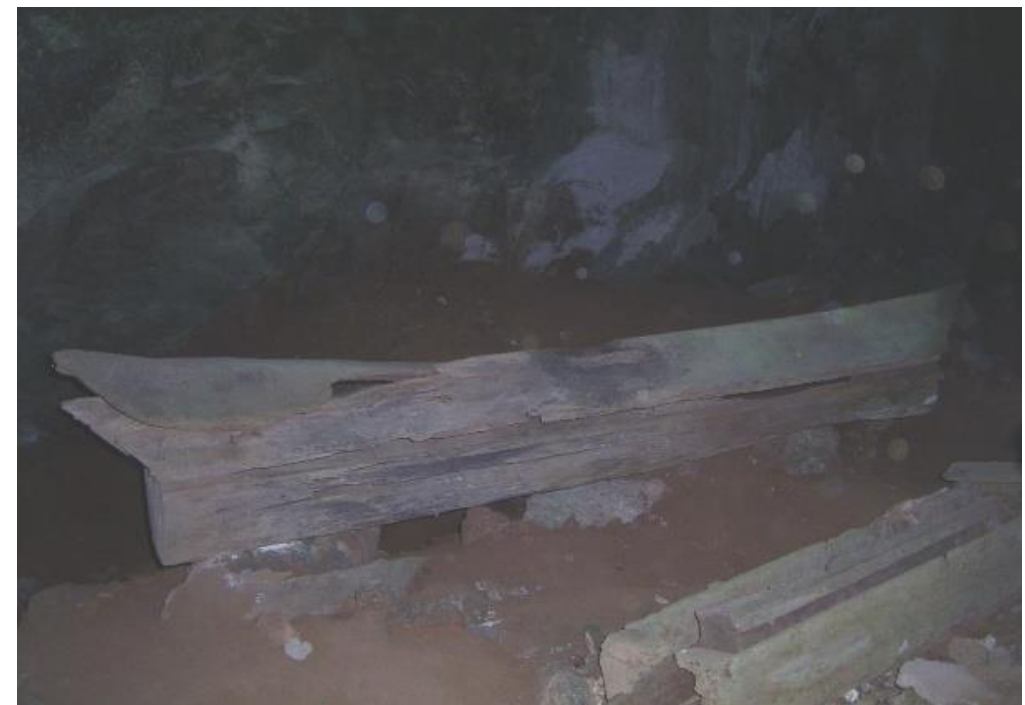

Figure 6. One of the wood coffins in Passea Ara Cave, in Bulukumba Regency (source: Hasanuddin et al, 2005, p. 141)

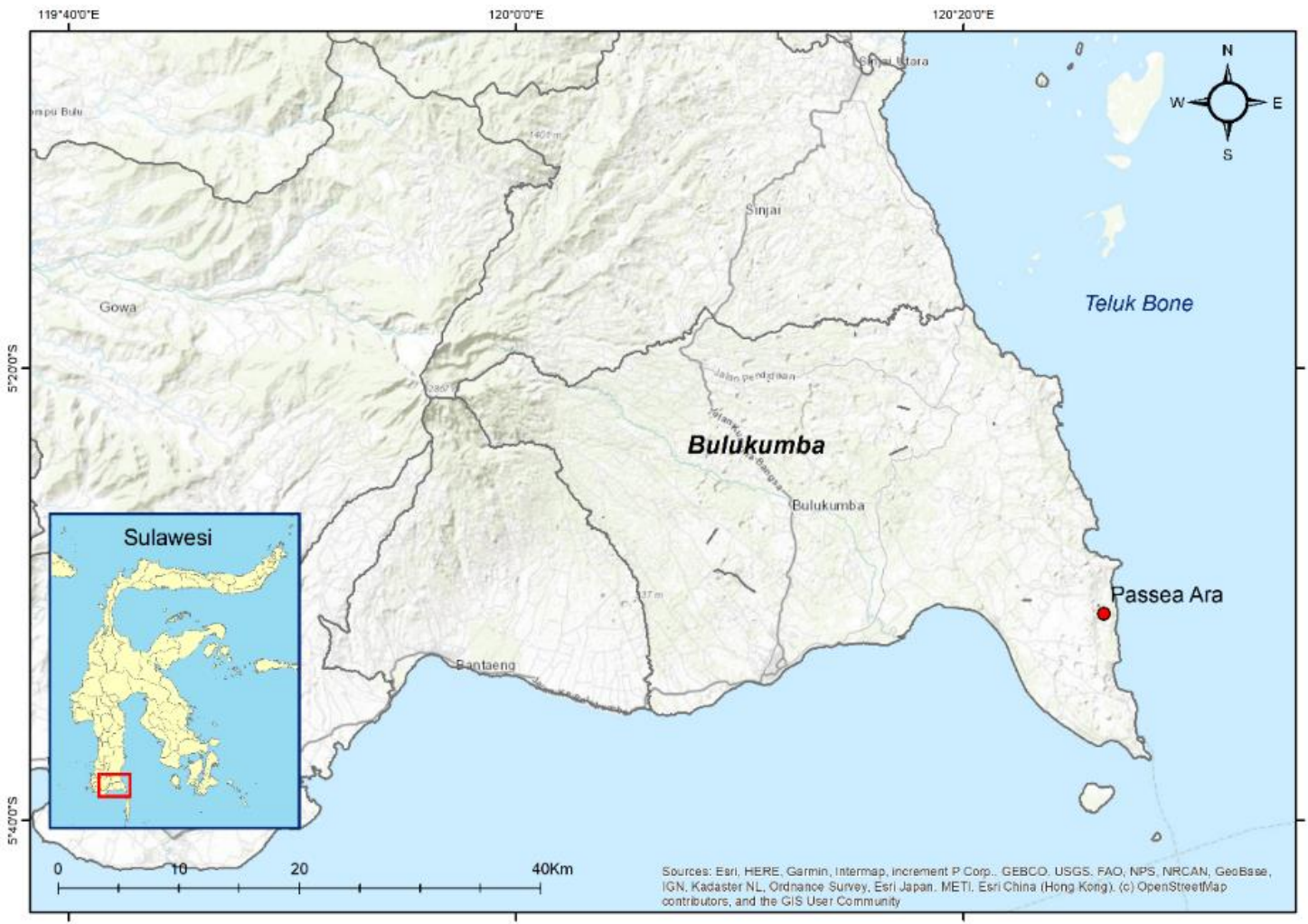

Figure 7. The location of Passea Ara Cave in Bulukumba Regency (source: the coordinates of the location as shown in the report of Busthanul's research, 1991).

southern coastal area and the eastern coastal area (Salman, 2006, pp. 30-31). Data obtained from the literature comparing results of previous relevant researches show that there is only one cave in Bulukumba that contains wood coffins. The cave is Gua
Passea Ara (Passea Ara Cave) (Figure 6) (Busthanul, 1991) and it is situated in the eastern coastal area of Bulukumba.

Passea Ara Cave is situated in Lambua Hamlet, Ara Village, Bonto Bahari Sub-district, Bulukumba Regency at the 
coordinates of $05^{\circ} 30^{\circ} 51,0^{\circ}$ South Latitude $120^{\circ} 26^{\circ} 17,7^{\circ}$ East Longitude. The elevation is $86 \mathrm{~m}$ above sea level (Figure 7). The entrance of Passea Ara cave faces east. Inside the cave, there are three wood coffins (Busthanul, 1991). The local community calls the coffins allung (Faiz, 2008, p. 44). The forms of the three coffins are like a boat (Faiz, 2008, p. 44; Wardaninggar, 1999, p. 81). Two of the coffins have a cover whose form is like the roof of a Bugis Makassar customary house while the cover of the other coffin has been damaged (Faiz, 2008, pp. 44-45). The coffins contain human bone remnants, earthenware fragments, and porcelain fragments from Sung, Ming, and Ching Dynasties (Faiz, 2008, p. 46). All the wood coffins in Passea Ara Cave are not decorated with ornaments (Busthanul, 1991, p. 48; Somba, 1999, p. 74), and now in the region, the tradition of burial with a wood coffin is not performed anymore.

\section{c. Enrekang}

Enrekang is a regency in the central part of South Sulawesi. It is a mountainous area and borders with Tana Toraja Regency. Most of its area is mountainous and only a small part of it is comprised by slightly bumpy hills and lowlands. The northern and central areas of Enrekang Regency are mountainous (Hasanuddin, 2015: 182). Due to such topographical features, it is natural that Enrekang Regency has many caves, and inside some of them, wood coffins have been found.

Cemetery cave sites containing wood coffins in Enrekang are called mandu and duni. Some of them are the Sites of Tontonan, Tocempa, Marengo, Kaluppini, Lo'ko Liang, and Lo'ko Mandu (Figure 8). Generally, the coffins are made of uru, bitti and cendana wood. Wood coffins are called erong by the Toraja community and widely distributed. They are almost always found in

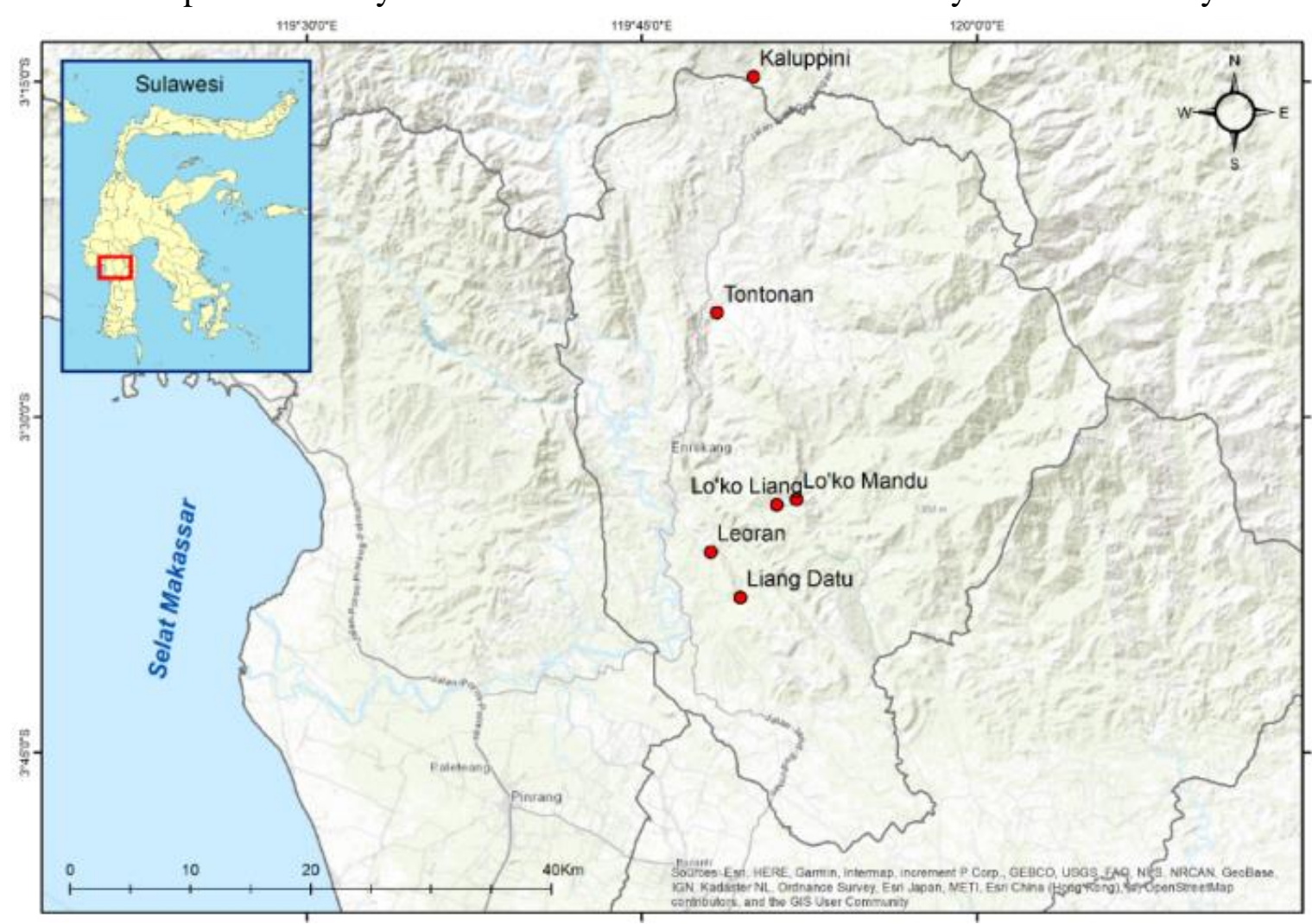

Figure 8. The locations of several caves that contain wood coffins in Enrekang Regency (source: the coordinates of the locations of the caves as shown in some research reports) 


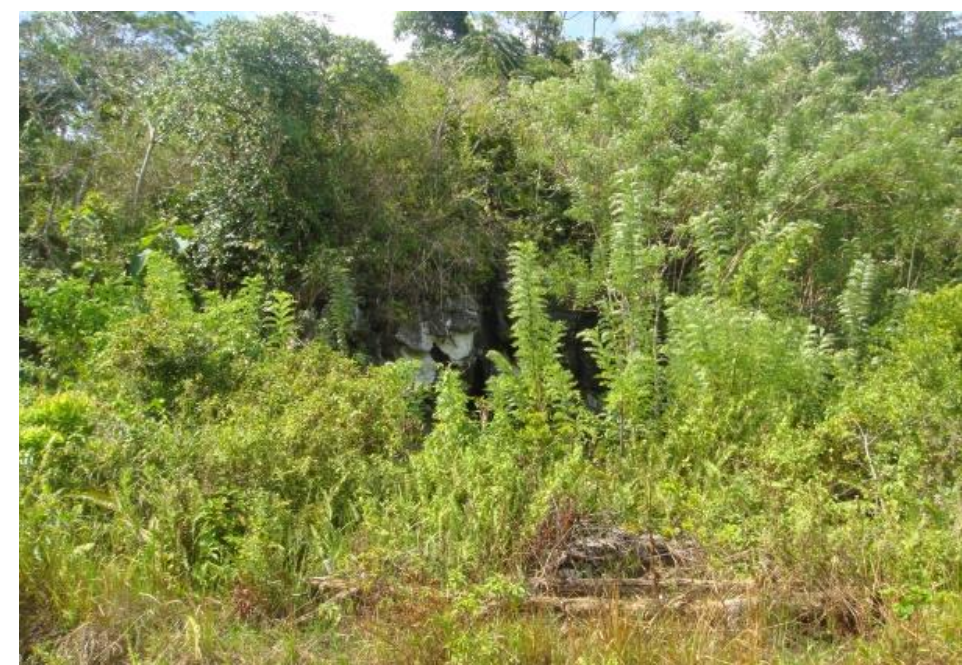

Figure 9. The entrance of Lo'ko Liang (source: Tim Balar Makassar, 2011)

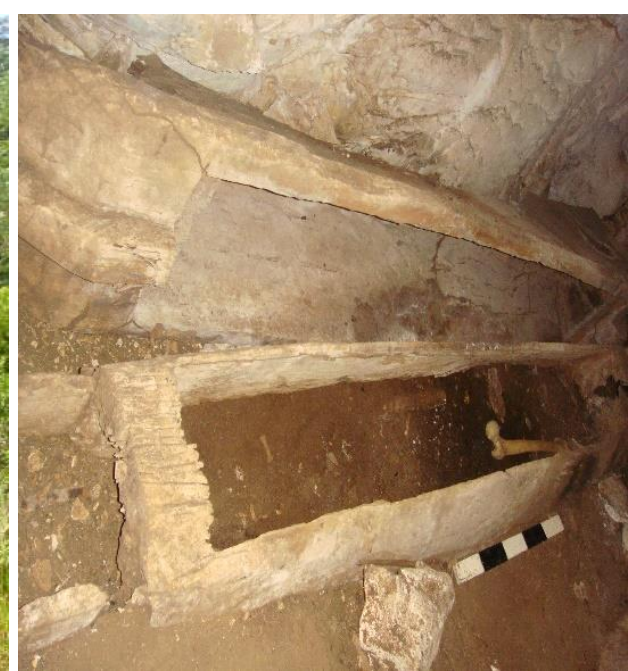

Figure 10. One of wood coffins in Lo'ko Liang (source: Tim Balar Makassar, 2011) cemetery cave sites (Tim Balar Makassar, 2011; Duli, 2013).

\section{The Site of Lo'ko Liang}

Administratively Lo'ko Liang is situated in Lembang Village, Enrekang Subdistrict, Enrekang Regency. Astronomically it lies at the coordinates of $03^{\circ} 33^{\prime} 55,5^{\prime \prime}$ South Latitude and $119^{\circ}$ 51'2,1" East Longitude with the elevation being 471 above sea level. The Site of Lo'ko Liang is a cemetery cave, which is a cavity on a rock cliff (Figure 9). Inside the cave, there are two separated rooms. In the first room, there is one wood coffin, called duni by the local community, which is made of bitti wood. This duni has been damaged, so that its form is difficult to identify. The length of this duni is $2 \mathrm{~m}$ and its width is $30 \mathrm{~cm}$. The cover is like a house roof. The length is $260 \mathrm{~cm}$, the width is $30 \mathrm{~cm}$, and the height is $28 \mathrm{~cm}$ (Laporan Penelitian Arkeologi di Kabupaten Enrekang, 2011).

A human skull that is not intact lies near the cave's entrance. At the second room, there is a tunnel that links it with the first room. Here there are 2 dunis. The second duni lies near the cave' entrance. The condition is fragile and damaged. The coffin is beam shaped. The length is $190 \mathrm{~cm}$, the height is $15 \mathrm{~cm}$, and the width is $30 \mathrm{~cm}$.
Inside the duni, there is a number of human bone remnants. The cover is like a house roof. The length is $260 \mathrm{~cm}$, the height is 35 $\mathrm{cm}$, and the width is $30 \mathrm{~cm}$ (Laporan Penelitian Arkeologi di Kabupaten Enrekang, 2011). The third duni lies inside the cave room. The condition is fragile and damaged. This duni is mortar shaped. The length is $250 \mathrm{~cm}$, the width is $28 \mathrm{~cm}$, and the height is $32 \mathrm{~cm}$ (Figure 10). Inside the duni, there are some human bone fragments. The cover is like a house roof. The length is 280 $\mathrm{cm}$, the width is $42 \mathrm{~cm}$, and the height is 32 $\mathrm{cm}$ (Laporan Penelitian Arkeologi di Kabupaten Enrekang, 2011).

\section{The Site of Lo'ko Mandu}

Lo'ko Mandu is situated about 500 metres north of Lo'ko Liang. Administratively the site is situated in Lembang Village, Enrekang Sub-district. Astronomically the site lies at the coordinates of $\mathrm{S} 03^{\circ} 33^{\prime} 41,8^{\prime \prime}$ and E $119^{\circ}$ 51 '55,8" with the elevation being $334 \mathrm{~m}$ above sea level (Figure 11) (Laporan Penelitian Arkeologi di Kabupaten Enrekang, 2011).

On the cave floor, two bunis lie. Both are starting to decay (figure 12). The first duni is without any cover. It is beam shaped. The length is $160 \mathrm{~cm}$, the width is $25 \mathrm{~cm}$, and 
the height is $25 \mathrm{~cm}$. The second duni is without any cover either. It is beam shaped. The length is $183 \mathrm{~cm}$, the width is $30 \mathrm{~cm}$, and the height is $30 \mathrm{~cm}$ (Laporan Penelitian Arkeologi di Kabupaten Enrekang, 2011).

\section{The Site of Liang Datu}

The site of Liang Datu is situated in Palakka Village, Maiwa Sub-district. Enrekang Regency at the coordinates of $03^{\circ} 338^{\prime} 04,6^{\prime \prime}$ South Latitude and $119^{\circ}$ 49'24,6" East Longitude with the elevation being $442 \mathrm{~m}$ above sea level. Liang Datu is a cemetery cave. There are 27 dunis inside the cave. Most of the Dunis still contain

human bones. The dunis are made of bitti and cendana wood. They are boad shaped and each of them has a cover which is like the roof of a customary house of the Toraja ethnic group (Figure 13) (Wardaninggar, 2011, pp. 140-141; Sriputri, 2013).

\section{The Site of Leoran}

In Enrekang Regency, wood coffins are generally found far from human settlements. The site of Leoran is situated in Galontak Village, Enrekang Sub-district, Enrekang Regency, South Sulawesi Province. The site lies at the coordinates of $03^{0} 36^{\prime} 02.8$ " South Latitude and

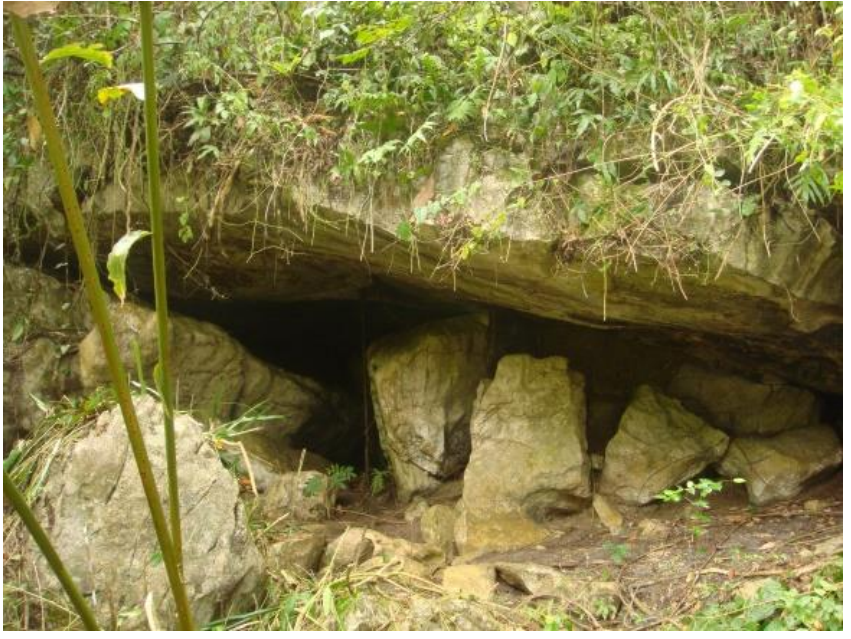

Figure 11. The entrance of Lo'ko Mandu Cave (source: Tim Balar Makassar, 2011)

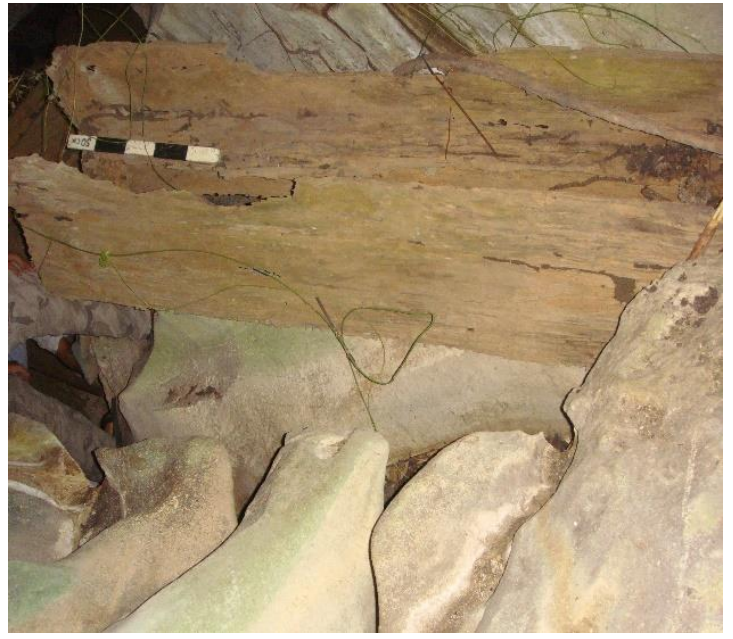

Figure 12. One of the wood coffins in Lo'ko Mandu (source: Tim Balar Makassar, 2011)

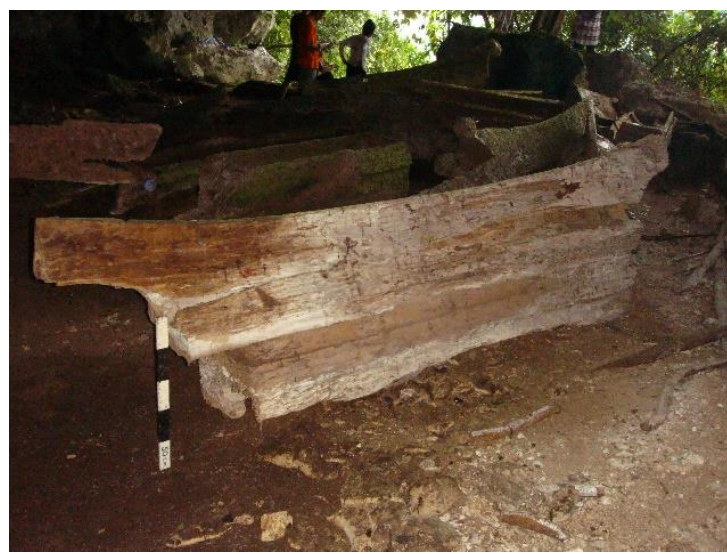

Figure 13. One of the boat-shaped wood coffins (source: Bernadeta, 2011, p. 140; also see Duli, 2013, p. 130)

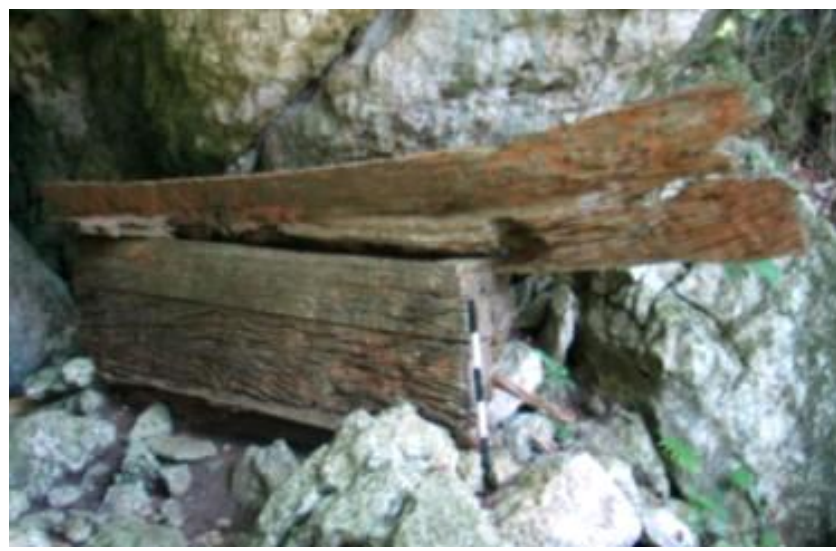

Figure 14. A wood coffin that is boat shaped in the Site of Leoran (source: Duli, 2013, p. 123) 


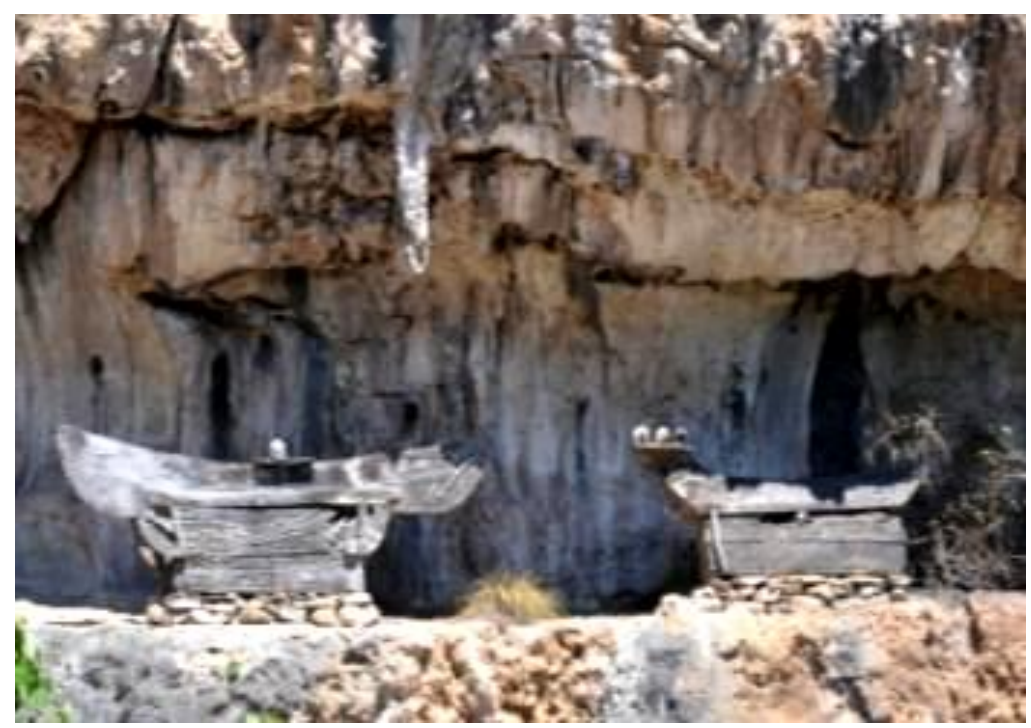

Figure 15. Wood coffins that are boat shaped on the Site of Tontonan (source: Duli, 2013, p. 127)

$119^{0} 48^{\prime} 05.8^{\prime \prime}$ East Longitude with the elevation being $421 \mathrm{~m}$ above sea level. The small wood coffins (figure 14) are made of cendana wood while the big ones are made of $u r u$ and bitti wood. Inside each of the coffins, there are human bones and a skull (Duli, 2013, p. 122).

\section{The Site of Tontonan}

The site of Tontonan is situated in Kampung Tontonan, Kelurahan Lakawan, Anggeraja Sub-district, Enrekang Regency, South Sulawesi Province. The site is situated on the cliff of Buntu Batu Tontonan with the elevation is $13 \mathrm{~m}$ above the cliff's base. At the cliff's base, Mataallo River flows and across the river, there is a human settlement. The site lies at the coordinates of $03^{0} 25^{\prime} 20.5^{\prime \prime}$ South Latitude and $119^{0} 48^{\prime} 21.8^{\prime \prime}$ East Longitude with the elevation being $518 \mathrm{~m}$ above sea level (Duli, 2012, p. 127).

The wood coffins on the site lie inside a cavity naturally formed at the middle part of the cliff wall by river water erotion (Figure 15) (Laporan Penelitian Arkeologi di Kabupaten Enrekang, 2011).. There are 12 wood coffins found on the site and they are placed according to the form of the cavity. All the coffins are square shaped and each of them has a cover whose form is like a boat.

\section{d. Toraja}

Tana Toraja is situated in the central part of Sulawesi Island. The elevation is about $800-1000 \mathrm{~m}$ above seal level. The topography of Tana Toraja Regency consists of mountainous areas (40\%), lowlands $(38 \%)$, and swamps, rivers, and valleys (2\%). Tana Toraja as a cultural region has various material heritages and customs and traditions that are still performed today. The wood coffins used in Tana Toraja reflect the various values upheld by the community (Duli et al., 2019; Hasanuddin, 2003, 2015; Wardaninggar, 2011, pp. 135-136).

Tana Toraja Regency and Toraja Utara Regency have a number of cemetery sites containing wood coffins called Erong. The tradition of burial with a wood coffin is still performed today in those two regencies. This section will discuss several sites in Toraja Utara that contain wood coffins placed in liang (caves). The Sites of Marante Tondon, Lombo' Bori' and Ke'te' Kesu' are selected for objects of comparison (Figure 16) because their various forms and ornaments reflect the belief and cultural 


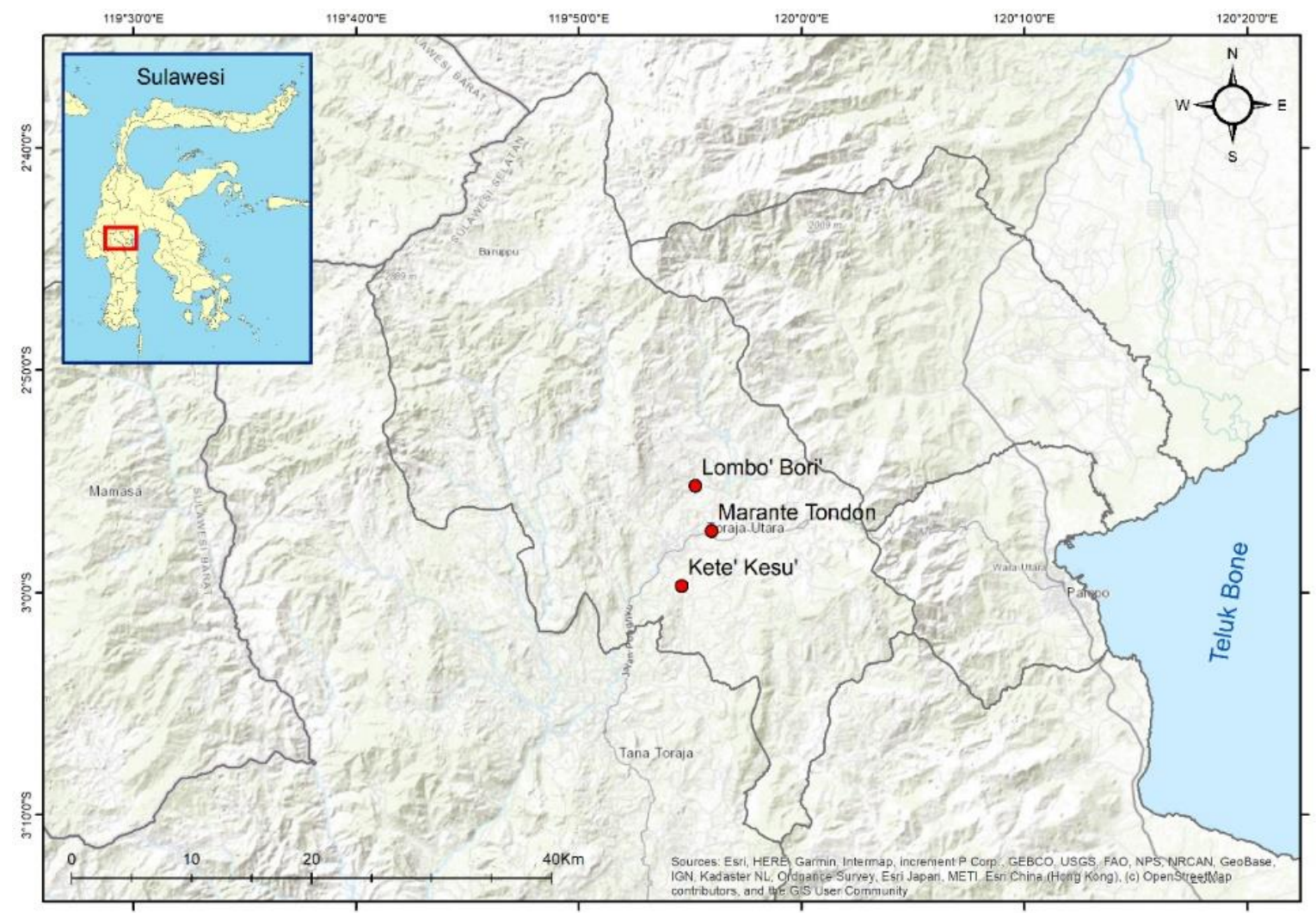

Figure 16. The locations of the caves that contain wood coffins (erong) in Toraja Utara Regency (source: the coordinates of the locations as shown in some research reports)

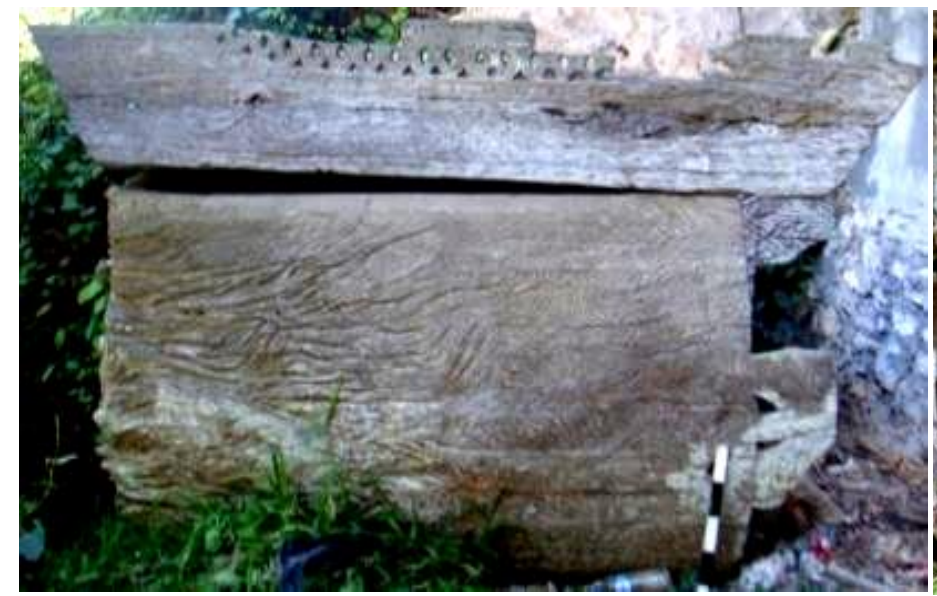

Figure 17. A wood coffin (Erong) on the site of Marante Tondon, Toraja Utara (source: Duli, 2012,p. 106)

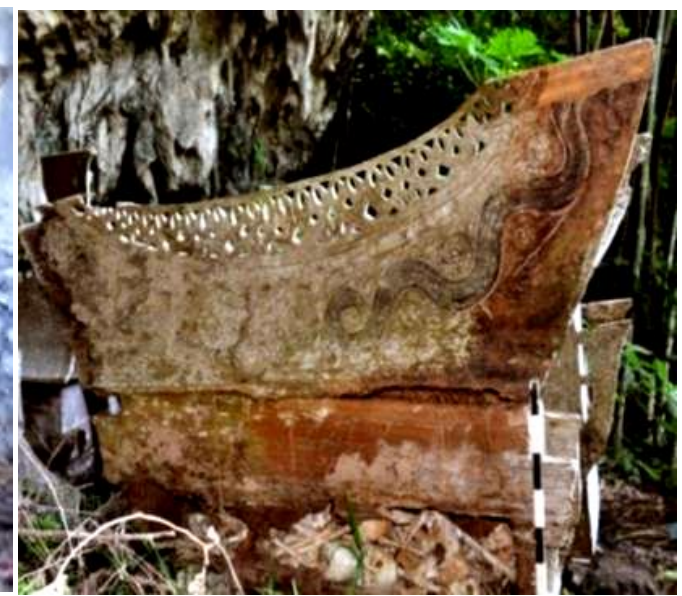

Figure 18. An Erong in the form of a boat with various ornaments, such as snake and human ornaments (source: Duli, 2012, p. 115) system that are still upheld and practiced by the Toraja community today.

\section{The Site of Marante Tondon}

The site of Marante Tondon is situated in Kampung Marante, Tondok Batu
Village, Tondon Sub-district, Toraja Utara Regency, South Sulawesi Province at the coordinates of $02^{0} 57^{\prime} 14.5^{\prime}$ "South Latitude and $119^{0} 55^{\prime} 58.4$ " East Longitude with the elevation being $830 \mathrm{~m}$ above sea level. On this cave site, there are 11 Erongs with a 


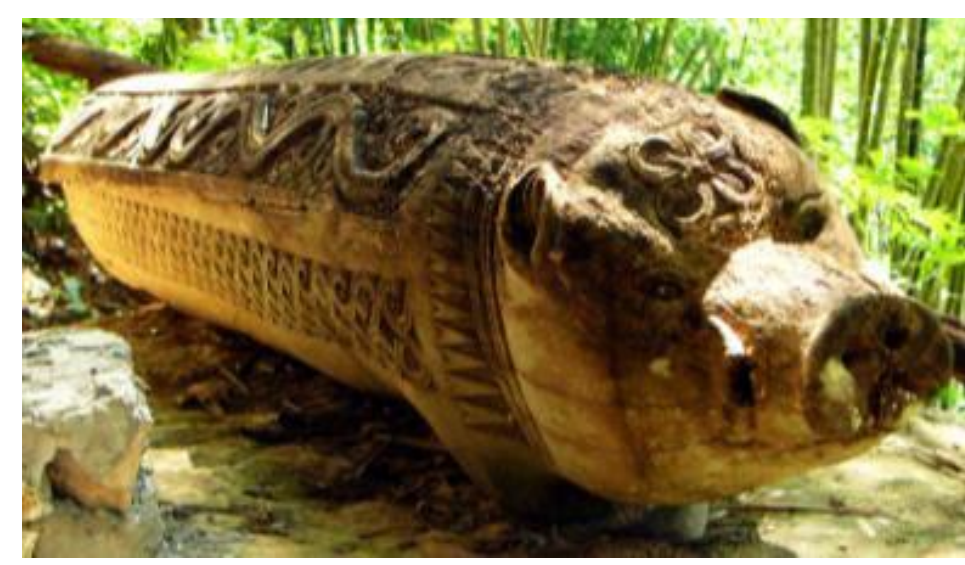

Figure 19. An Erong in the form of a pig in the site of Ke'te' Kesu', Toraja Utara (source: Duli, 2012, p. 117)

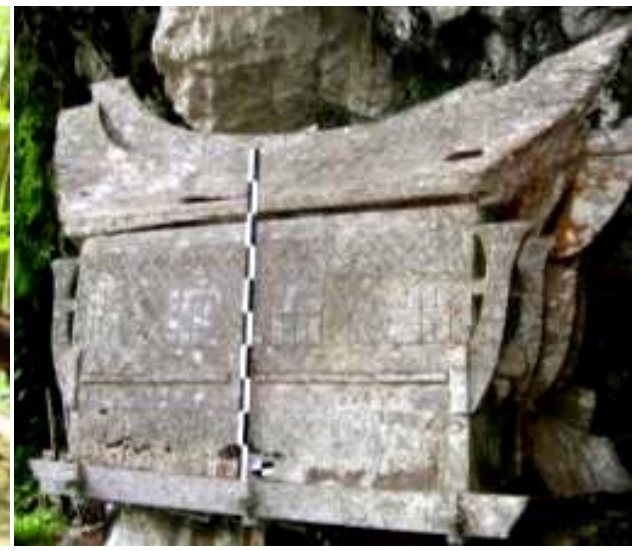

Figure 20. A wood coffin Erong in the form of a boat with various ornaments on the site of Ke'te' Kesu' in Toraja Utara Regency (source: Duli et al, 2019, p. 2)

variety of forms, which are the form of a boat (Figure 17), the form of a buffalo, and some other unclear forms because the coffins are damaged. Some of the coffins are decorated with ornaments (Duli, 2012, p. 104).

\section{The Site of Lombo' Bori'}

The site of Lombok is situated in Kampung Lombok, Kelurahan Bori' Parinding, Sesean Sub-district at the coordinates of $02^{0}$ 55'13.2" South Latitude, $119^{0} 55^{\prime} 14.0^{\prime \prime}$ East Longitude with the elevation being $825 \mathrm{~m}$ above seal level. The site is a rock niche naturally formed as a result of some limestone formation. Inside the niche and in its yard, there are erongs in various forms and places (Wardaninggar, 2011,p. 138). The erongs are in the forms of a boat and a customary house. The whole body and cover of the boat shaped erongs are decorated with many Torajan ornaments, such as snake ornaments (figure 18), human ornaments and buffalo ornaments (Duli, 2012, pp. 111113).

\section{The Site of Ke'te' Kesu'}

The site of Ke'te Kesu' is situated in Kesu' Malenong Village, Sanggalangi Subdistrict, Toraja Utara, at the coordinates of $02^{0} 59^{\prime} 43.2^{\prime \prime} \quad$ South Latitude and $119^{0} 54^{\prime} 38.1$ " East Longitude with the elevation being $798 \mathrm{~m}$ above sea level (Duli,
2012, p. 115; Hasanuddin, 2003, p. 38). On the site of Ke'te' Kesu', there are 64 erongs. $55(86 \%)$ of them are boat shaped, 7 (10.9\%) of them are buffalo shaped, and $2(3.1 \%)$ of them are pig shaped (figure 19). 51 (79.7\%) of them are still intact and $13(20.3 \%)$ of them are not intact. $48(75 \%)$ of them are decorated with ornaments dan $16(25 \%)$ of them do not have ornaments. All the erongs are placed on the surface of the liang (cemetery site) soil and the number of erongs hung on the cliff wall is 21 (Duli, 2012, p. 116).

There are also erongs that are boat shaped. The body is semicircle. The cover is like the roof of a Tongkonan house (the customary house of Toraja). All the surface is decorated with Torajan carvings, like rhombus, sun and tendril carvings (Figure 20).

\section{Wood Coffins in Southeast Sulawesi}

One of the focuses of this research is Kolaka Utara Regency. Kolaka Utara was established as a regency in 2003, as a result of the split of Kolaka Regency. Kolaka Utara lies in the northern tip of Southeast Sulawesi Province. The regency becomes the northen gate linking Southeast Sulawesi Province to South Sulawesi Province. 


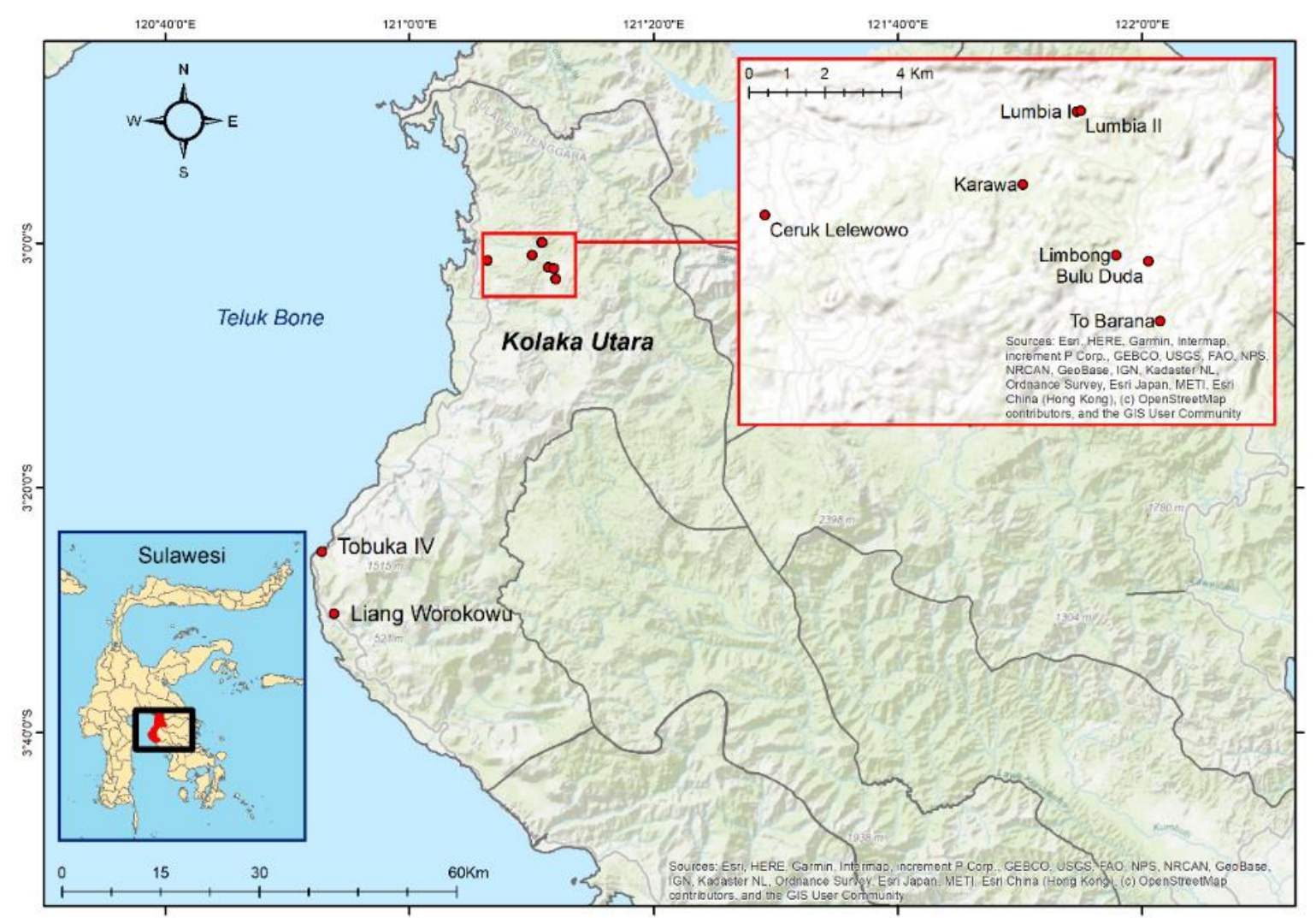

Figure 21. The locations of several caves/niches that contain wood coffins in Kolaka Utara Regency, Southeast Sulawesi (source: the coordinates of the locations as shown in some research reports)

Kolaka Utara Regency stretches from the north to the south, at the coordinates of $120^{\circ} 45^{\prime} 00^{\prime \prime}-120^{\circ} 30^{\prime} 13^{\prime \prime}$ East Longitude and $02^{\circ} 00^{\prime} 00^{\prime \prime}-03^{\circ} 30^{\prime} 00^{\prime \prime}$ South Latitude. The topography consists of valleys, hills, mountains and sea (Laporan Penelitian Arkeologi di Kabupaten Kolaka Utara, 2008).

The number of caves and niches that have been surveyed by Makassar Archaeology Office in 2008 is 9. They are situated in five sub-districts (Figure 21). The remnants inside the caves and niches become evidence of burials with a wood coffin which was placed inside a cave or a niche. Data that can be used as a strong variable are the evidence of human burials in caves and niches and various items used as grave goods. The tradition of burial with a wood coffin practiced by its supporting communities is an activity performed repeatedly, which is proved by bone fragments, human skulls, and various items that might function as grave goods, such as beads, coins, rings, bronze bracelets, necklaces and earthenware, which are found on the sites (Laporan Penelitian Arkeologi di Kabupaten Kolaka Utara, 2008).

The archaeological findings in a number of caves and niches used as a burial place show a similarity in human behavior in that some communities in certain periods of time performed the tradition of burial in caves or niches formed on limestone mountain ranges with the elevation being 136-145 $\mathrm{m}$ above sea level. It is very regrettable that several caves that used to be used as a burial place now have been closed by stones by some individuals who carry out plantation activities around the caves (Laporan Penelitian Arkeologi di Kabupaten Kolaka Utara, 2008).

The cemetery cave sites in Kolaka Utara contain the remnants of human bones 


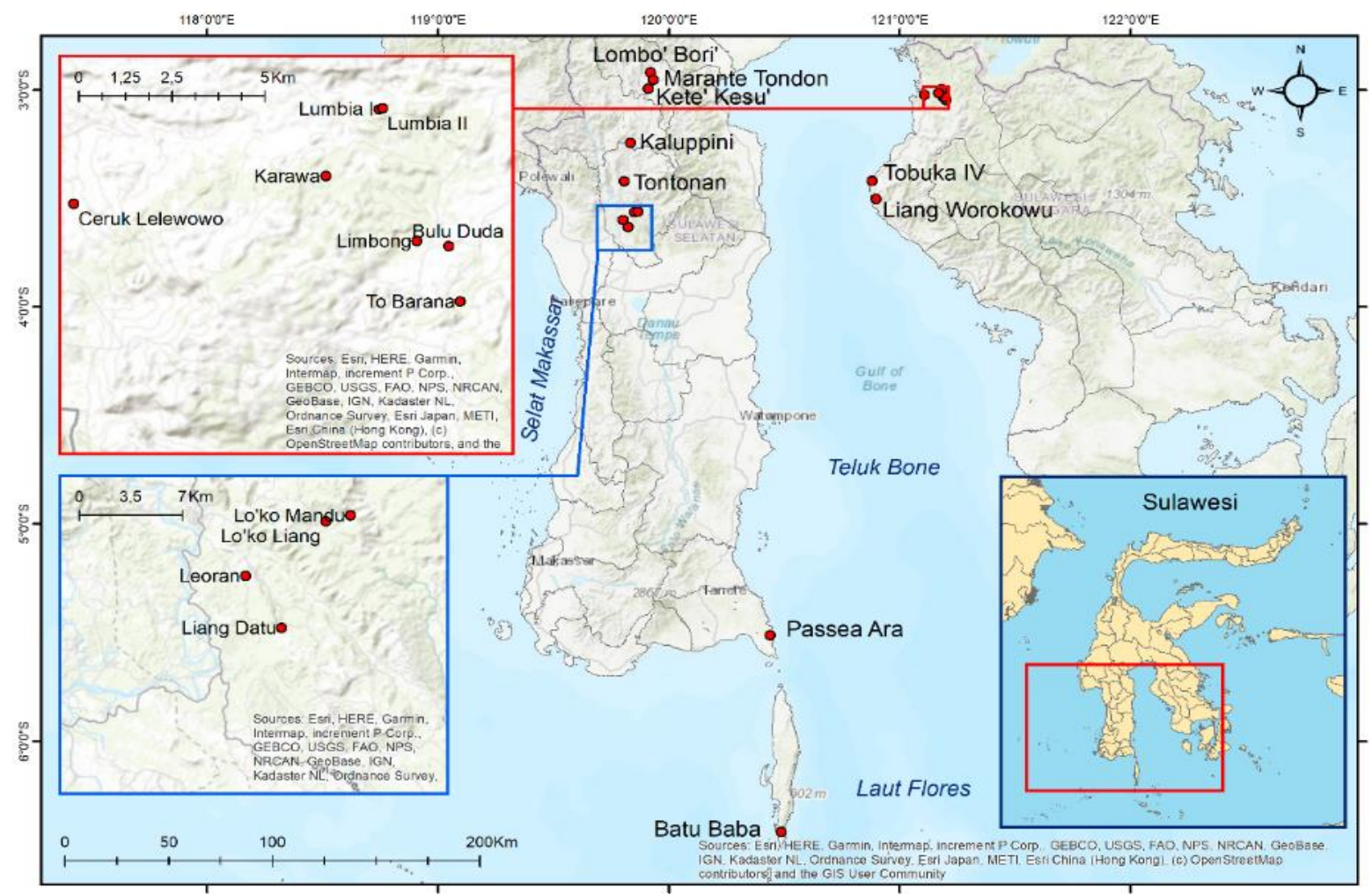

Figure 22. The distribution of wood coffin sites in the coastal areas and the hinterlands (source: the coordinates of the sites' locations as shown in some research reports)

and wood coffin fragments. The research conducted by Effendy and Mannan (1995) found many holes as a result of illegal digs and scattered foreign ceramic fragments, human bones, bronce bracelets and clamshells (gastropoda). The findings of Effendy and Mannan (1995) are not far different from those of Wardaninggar et al. (2010) and Muhaeminah et al. (2012). One of the cave sites that have been proven as a burial place is the Site of Watumea where human bone fragments have been found. The Site of Watumea is the location of the burial of Kings (mokole) Watumea and their families (Yasni \& Suseno, 2019, p. 30).

\section{Distribution of Wood Coffins}

The distribution of wood coffins in South Sulawesi and Southeast Sulawesi covers the regions of Toraja, Enrekang, Selayar, and Bulukumba (South Sulawesi), and Kolaka Utara (Southeast Sulawesi). The distribution of cave and niche sites covers the coastal areas and hinterlands (Figure 22). The wood coffins found in the coastal areas and the hinterlands have the same basic form, i.e. the form of a boat or a mortar with the cover having the form of a customary house. This similarity indicates that the same group of ancestors brought the tradition of burial with a wood coffin to several regions in Sulawesi. The similarity also indicates that the tradition actually originated from the same cultural root, i.e. the Austronesian one.

The tradition of burial with a wood coffin placed in a cave started to be practiced in Indonesia, especially Sulawesi, at the same time when Austronesian migrants came in Nusantara. Then in South Sulawesi, the tradition became more refined in the $12^{\text {th }}$ and $13^{\text {th }}$ centuries. In Tana Toraja, the tradition was practiced around $1130 \pm 50 \mathrm{BP}$, in Enrekang around 790 $\pm 50 \mathrm{BP}-570 \pm 40 \mathrm{BP}$ 
and in Mamasa around 730 $\pm 50 \mathrm{BP}$ (Duli, 2013; 2019).

\section{Factors Causing Differences and Similarities in the Forms of Wood Coffins}

Some typological similarities among dunis and mandus, the wood coffins in Enrekang, dan erongs, the wood coffins di Toraja, indicate that there is a cultural relationship between the two regions. However, erongs in Toraja are decorated with many ornaments on the cover and body, while dunis in Enrekang rarely have carvings on the cover and body.

The wood coffins in Toraja have undergone some innovations. They are decorated with ornaments in the forms of animals, like a buffalo and a pig with various sizes. The forms of the coffin bodies are varied and have more developed ornaments.

The forms of wood coffins that are like an animal are found only in Toraja, especially in areas where the community strongly adheres to their ancestral belief called aluk todolok. The wood coffins in Toraja, whether they are in the form of a boat or a customary house of Toraja or whether they are in the form of a buffalo or a pig, are considered as a vehicle for transporting the spirit of a dead person to the spirit world (Duli, 2012; Wardaninggar, 2011).

Another difference lies in the continuity of tradition. In the northern regions of South Sulawesi, which are mountainous, like Enrekang and Toraja, many wood coffins have been found in caves or niches. The mountainous topography of these regions has enabled old traditions to be maintained. One example is the region of Toraja. The community of Toraja has lived in isolated mountainous areas from generation to generation. This geographical isolation has made them difficult to make interaction with people from outside their region, which in turn has resulted in the continuity of their old culture and traditions. Today the community of Toraja still performs their old traditions, including their funeral tradition, which is carried out on a large scale and accompanied with the making of a wood coffin for the dead person and the erection of a simbuang menhir (Hasanuddin, 2015, p. 389).

A religion, a belief or the concept of sanctity is one part of a culture that is difficult to change because it is the core of a culture. Therefore, many prehistoric religions have survived until today, especially among the communities living in hinterlands (Simanjuntak \& Widianto, 2012: 343-344). The coming of new religions in Toraja did not get rid of old traditions, and the basic ideas of the embraced new beliefs have similarities with the ones of the replaced old ideologies (Simanjuntak \& Widianto, 2012, p. 344).

Unlike the community of Toraja, the community of Enrekang, although living in hilly and mountainous areas, does not use wood coffins anymore for burying a dead person. Due to the strong influence of Islam in the region of Enrekang, the tradition of burial with a wood coffin called duni or mandu is not performed anymore. Some elements of the belief systems of the community in Enrekang survived until the $13^{\text {th }}$ century (Duli, 2013).

The form of belief embraced by the Tolaki ethnic group and their tradition of burial with a wood coffin ethnographically have similarities with those embraced and performed by the community of Toraja. This is natural because the Tolaki ethnic group who live in Southeast Sulawesi are cognate with the ethnic groups of Toraja, To Mori, To Bungku (To Bunggu) and others (Tarimana, 1989).

The dunis in the form of a boat are thought to have a close relationship with the coming of the ancestors of the Torajan people in the region of Toraja with boats. It is said that they migrated from their place of origin with boats as their means of transport. Later, the boats that they used were immortalized in the forms of their customary 
houses and wood coffins. It is likely that the tradition of burial with a wood coffin was distributed by those people coming with boats and, when they died, they were buried inside a boat. Later after these migrants moved to live in the hinterlands, for burying a dead person, they made a wood coffin in the form of a boat and put the dead body inside it. The tradition of putting a dead body inside a wood coffin that is boat shaped is still performed by the community of Dayak Ngaju in Kalimantan and the community of Toraja (Hartatik, 2007, pp. 63-69; Poesponegoro \& Notosusanto, 2011; Simanjuntak \& Widianto, 2012, pp. 346347).

To the ethnic groups living in coastal areas, especially seafaring peoples, boats are very meaningful in their daily life. Boats are a means of transport in their daily life, so that they believe that the spirit of a dead person will be transported to an island across the sea where the spirit will abode. Because of this, the wood coffins used by seafaring peoples living in coastal areas are boat shaped. As has been said, the coffins are made like a boat due to the great service of boats in the coming of their ancestors to their regions.

The communities living in coastal areas have long made a contact with immigrants bringing with them their cultures. The contact has resulted in new cultures in various types and forms. Coastal areas are open areas in that they are always exposed to foreign influences. The acceptance of new cultures and religions, including Islam, had some influence on the cultures that had previously been embraced. The majority of the Muslim communities uphold strict religious rules. Due to this, some old cultural elements are not embraced anymore (Hasanuddin, 2015, pp. 386-387).

In general, funeral activities and processes are rituals to fulfill religious emotional needs performed collectively and repeatedly in a certain place and time. These rituals become interaction media to form and convey messages in the forms of symbols. The burial of a dead person in a wood coffin and the placing of the coffin on a site where some other coffins have been placed symbolize that the spirit of the dead person will live together with the other spirits in the spirit world. The tradition of burial with a wood coffin also reflects a form of solidarity among the kinships of the dead person and the whole community (Wiradnyana, 2013, p. 168).

\section{CONCLUSION}

The results of the literature study on the typology of wood coffins (erong, dunia or mandu and allung) indicate that the tradition of burial using a wood coffin is closely related to their acquaintance with metal tools. All the researched wood coffins are similar in that their basic forms are like a boat. However, the wood coffins in Toraja have undergone an innovation; some of them are in the form of a pig. The belief factor has also contributed the practice of burial with a wood coffin.

Results of the research show that wood coffins have been found in caves in Selayar, Bulukumba, Enrekang and Toraja. In Southeast Sulawesi, wood coffins have been found mainly in caves in Kolaka Utara. These findings of wood coffins in those regions indicate that in the past the communities had a certain cultural system inherited from their ancestors. They were the heirs of the cultures of the ethnic groups of Bugis, Makassar and Toraja living in South Sulawesi and the ethnic group of Tolaki living in Southeast Sulawesi.

The wood coffins found in Toraja show that the burial with a wood coffin placed in a cave in Toraja (South Sulawesi) started in the $8^{\text {th }}$ century $(1130 \mathrm{BP}-50 \mathrm{BP})$. The traditions of making wood coffins and burying a dead person with a wood coffin are still performed today.

Such traditions in Toraja are preserved because the community still strongly adheres to their ancestral belief called aluk todolok. This is not the case with 
the communities in the coastal areas, such as Bulukumba and Selayar, and the communities in the hinterlands, such as Enrekang. They are fanatical adherents of Islam. Due to this, the tradition of burial with a wood coffin placed in a cave is not performed anymore in those regions and some of the wood coffins have been left unmaintained.

The communities in South Sulawesi and southeast Sulawesi are similar in that they used to use wood coffins placed in caves or niches. This similarity indicates that there was a close relationship in the past among the communities, and this relationship was strengthened by their shared cultural roots introduced by some of the Austronesian peoples, who were key to the ethnogenesis of the Indonesian people. Although the ethnic groups living in
Sulawesi show pluralism and multiculturalism, they have the same cultural roots.

\section{Acknowledgement}

We would like to express our gratitude to Dr. Hasanuddin, M.Hum. for having supervised the writing of this article. We also would like to express our gratitude to all the team members for their help in the collection of literature data. Our gratitude also goes to Khaidir Sirajuddin for having made a map based on the astronomical coordinates of the sites' locations obtained from various sources.

\section{REFERENCES}

Arsyad, D. (2017). Wadah Kubur Kayu Soronga di Situs Gua Tokandindi, Kecamatan Bungku Barat, Kabupaten Morowali, Sulawesi Tengah. Universitas Hasanuddin.

Bulbeck, D., \& Hakim, B. (2005). The Human Fossil Cranium From Leang Batu Tunpa, Selayar, Sulawesi Selatan. In Menguak Tabir Kehidupan Masa Lalu dan Kini. Makassar: Hasanuddin University Press.

Busthanul, A. (1991). Wadah Kubur di Gua Passea Ara Kabupaten Bulukumba (Suatu Deskriptif Analitis). Universitas Hasanuddin.

Duli, A. (2012). Budaya Keranda Erong di Tana Toraja, Enrekang dan Mamasa, Sulawesi, Indonesia. Universiti Sains Malaysia.

Duli, A. (2013). The Mandu Coffin: A Boat Syimbol of Ancestral Spirits Among the Enrekang People of South Sulawesi. Journal RIMA, 47(1).

Duli, A., Nur, M., Hasanuddin, Rosmawati, Chia, S., \& Ramli, Z. (2019). The Role of Radiocarbon Analysis in Determining The Chronology of Erong Culture in Tana Toraja. Journal of Physics: Conference Series, 1341 08200. https://doi.org/10.1088/17426596/1341/8/082008

Effendy, M. A. R., \& Mannan, S. (1995). Objek Peninggalan Sejarah dan Purbakala di Kabupaten Kolaka. Makassar.

Faiz. (2008). Allung dan Duni sebagai Media Penguburan pada Gua - Ceruk di Sulawesi Selatan (Tinjauan Etnoarkeologi). Universitas Hasanuddin.

Harsyad. (1993). Pola Penguburan Dalam Gua di Lowa, Selayar : Studi Komparasi Mengenai Sistem Penguburan Wadah Kayu Di Sulawesi Selatan. Universitas Hasanuddin.

Hartatik. (2007). Penguburan Masyarakat Dayak dan Toraja dalam Perbandingan. Naditirawidya, 1(1).

Hasanuddin. (2003). Pola Pemukiman Masyarakat Toraja. In A. Duli \& Hasanuddin (Eds.), Toraja Dulu dan Kini (pp. 35-61). Makassar: Pustaka Refleksi. 
Hasanuddin. (2009). Indikasi Permukiman Situs-situs Berciri Austronesia di Pantai Timur dan Selatan Pulau Selayar. Walennae: Jurnal Arkeologi Sulawesi Selatan Dan Tenggara, 11(2), 83-98.

Hasanuddin. (2015). Kebudayaan Megalitik di Sulawesi Selatan dan Hubungannya dengan Asia Tenggara. Universiti Sains Malaysia.

Hasanuddin, A., Umar, F., \& Asfriyanto. (2005). Spektrum Sejarah Budaya dan Tradisi Bulukumba. Makassar: Hasanuddin University Press.

Kadir, H. (1989). Nekara Selayar dalam Konteks Asia Tenggara. Pertemuan Ilmiah Arkeologi V, Buku IV, 90-106.

Laporan Penelitian Arkeologi di Kabupaten Enrekang. (2011). Makassar.

Laporan Penelitian Arkeologi di Kabupaten Kolaka Utara. (2008). Makassar.

Moleong, L. J. (2008). Metodologi Penelitian Kualitatif (Edisi Revi). Bandung: PT Remaja Rosdakarya.

Muhaeminah. (2012). Jejak Sejarah dan Lintasan Budaya Suku Tolaki di Wilayah Sulawesi Tenggara. Makassar.

Pelras, C. (2006). Manusia Bugis (Terjemahan; Abdul Rahman Abu, Hasriadi, \& N. Sirimorok, Eds.). Jakarta: Nalar bekerjasama dengan Forum Jakarta-Paris, EFEO.

Poesponegoro, M. D., \& Notosusanto, N. (2011). Sejarah Nasional Indonesia I: Zaman Prasejarah di Indonesia (edisi pemutakhiran) (5th ed.; M. D. Poesponegoro \& N. Notosusanto, Eds.). Jakarta: Balai Pustaka.

Saifuddin, A. (2001). Metode Penelitian. Yogyakarta: Pustaka Pelajar.

Salman, D. (2006). Jagad Maritim. Makassar: Ininnawa.

Simanjuntak, T. (2008). Austronesian in Sulawesi: Its Origin, Diaspora, and Living Tradition. In Truman Simanjuntak (Ed.), Austronesian in Sulawesi (pp. 215-237). Center for Prehistoric and Austronesian Studies.

Simanjuntak, T., \& Widianto, H. (2012). Indonesia dalam Arus Sejarah. Jakarta: PT. Ichtiar Baru van Hoeve Kerjasama Kemendikbud.

Somba, N. (1999). Sistem Penguburan Wadah Kayu di Sulawesi Selatan. Walennae: Jurnal Arkeologi Sulawesi Selatan Dan Tenggara, 3, 73-78.

Sriputri, E. (2013). Bentuk Duni pada Situs Liang Datu Kabupaten Enrekang (Studi Komparasi). Universitas Hasanuddin.

Tarimana, A. (1989). Kebudayaan Tolaki Seri Etnografi Indonesia. Jakarta: Balai Pustaka Depdikbud.

Wardaninggar, B. A. K. (1998). Wadah Kubur Erong di Tana Toraja: Tradisi Tekno-Religi Megalitik. Walennae: Jurnal Arkeologi Sulawesi Selatan Dan Tenggara, 2, 25-34.

Wardaninggar, B. A. K. (1999). Bentuk-bentuk Wadah Kubur Kayu di Sulawesi Selatan dan Tenggara. Walennae: Jurnal Arkeologi Sulawesi Selatan Dan Tenggara, 3, 79-85.

Wardaninggar, B. A. K. (2011). Erong, Salah Satu Bentuk Wadah Kubur di Tana Toraja, Sulawesi Selatan. Walennae: Jurnal Arkeologi Sulawesi Selatan Dan Tenggara, 13(2), 133-146.

Wibisono, S. C. (1991). Perubahan Pola Permukiman di Pulau Selayar Suatu Kajian Arkeologi Permukiman. Universitas Indonesia.

Wiradnyana, K. (2013). Makna Penguburan Bersama Masa Prasejarah dan Tradisinya di Sumatera Bagian Utara. Berkala Arkeologi Sangkhakala, 16(2).

Yasni, A. A., \& Suseno, S. (2019). Konsevasi Wadah Kubur (Soronga) di Museum Provinsi Sulawesi Tenggara. Jurnal Penelitian Arkeologi, 3(2). 